\title{
Connecting Rod Device
}

National Cancer Institute

\section{Source}

National Cancer Institute. Connecting Rod Device. NCI Thesaurus. Code C49884.

A rod designed to transmit motion between moving parts. 